\title{
PENGARUH TEMPERATUR DAN IRADIASI TERHADAP INTERDIFUSI PARTIKEL BAHAN BAKAR JENIS U-7Mo/AI
}

\author{
Maman Kartaman A, Aslina Br. Ginting, Supardjo, Boybul \\ Pusat Teknologi Bahan Bakar Nuklir-BATAN \\ Kawasan Puspiptek, Serpong, Tangerang Selatan, 15314 \\ e-mail: makar@batan.go.id
}

(Naskah diterima : 16-12-2015, Naskah direvisi: 06-01-2016, Naskah disetujui: 19-01-2016)

\section{ABSTRAK}

PENGARUH TEMPERATUR DAN IRADIASI TERHADAP INTERDIFUSI PARTIKEL BAHAN BAKAR JENIS U-7Mo/Al. Paduan U-7Mo/Al memiliki potensi besar sebagai bahan bakar reaktor riset, tetapi bahan bakar ini memiliki beberapa kekurangan antara lain dapat membentuk interaction layer pada antarmuka pada saat proses fabrikasi maupun iradiasi di reaktor melalui mekaniame difusi. Penelitian ini dilakukan untuk mengetahui terjadinya interaction layer yang disebabkan oleh interdifusi atau diffusion couple paduan $\mathrm{U}-7 \mathrm{Mo}$ dengan pelat AIMg2 yang dipanaskan pada temperatur $500{ }^{\circ} \mathrm{C}$ dan $550{ }^{\circ} \mathrm{C}$ selama 24 jam dalam tungku arc furnace dan tungku DTA pada temperatur $30{ }^{\circ} \mathrm{C}$ hingga $1400{ }^{\circ} \mathrm{C}$. Hasil pengamatan mikrostruktur menggunakan Scanning Electron Microscope (SEM) pada sampel diffusion couple hasil pemanasan pada temperatur $500{ }^{\circ} \mathrm{C}$ belum terlihat adanya interaction layeratau pembentukan fasa baru antara partikel U-Mo dan matriks Al. Sementara itu, pemanasan pada temperatur $550{ }^{\circ} \mathrm{C}$ telah terjadi interdifusi paduan $\mathrm{U}-7$ Mo dengan pelat AIMg2 menghasilkan senyawa (U,Mo)Alx pada antarmuka atau interface. Hal ini didukung oleh hasil analisis DTA menunjukkan bahwa paduan $\mathrm{U}-7 \mathrm{Mo} / \mathrm{Al}$ pada $500{ }^{\circ} \mathrm{C}$ mempunyai kompatibilitas panas yang baik, tetapi diatas temperatur $550{ }^{\circ} \mathrm{C}$ telah terjadi perubahan fasa $\alpha+\delta$ menjadi $\alpha+\gamma$. Pemanasan hingga $679,14^{\circ} \mathrm{C}$ terjadi fasa metastabil U(Al,Mo)x dan selanjutnya mengalami proses interdifusi dengan leburan uranium membentuk interaction layer berupa aglomerat senyawa UAlx (UAl $l_{4}, U A l_{3}$ danUAl 2 ). Aglomerat yang terbentuk dari proses pemanasan secara diffusion couple maupun dalam tungku DTA dibandingkan dengan aglomerat yang terbentuk akibat proses iradiasi. Bahan bakar paduan U-7Mo/Al yang diradiasi dengan burn up 58\% mengalami interdifusi antara U-7Mo dengan matriks $\mathrm{Al}$ menghasilkan fasa metastabil $\mathrm{U}(\mathrm{Al}, \mathrm{Mo})_{\times}$yang berubah menjadi layer (U,Mo)Al7, presipitat $\mathrm{UMo}_{2} \mathrm{Al}_{20}$, $(\mathrm{UMo}) \mathrm{Al}_{3}-\mathrm{Al}$ dan membentuk boundary atau aglomerat $\mathrm{UAl} \mathrm{I}_{\mathrm{x}}\left(\mathrm{UA} \mathrm{l}_{4}\right.$, $\cup \mathrm{Al}_{3}$ danUAl${ }_{2}$ ). Data ini didukung oleh analisis kekerasan mikro menggunakan Hardness Vickers dilakukan terhadap kelongsong AIMg dan paduan U-7Mo (sebelum dan sesudah pemanasan) serta sampel diffusion couple U-7Mo/Al dengan pelat AlMg2 hasil pemanasan pada temperatur $550{ }^{\circ} \mathrm{C}$. Hasil analisis kerasan mikro yang diperoleh berturut-turut adalah 64,62 dan $340,45 \mathrm{HV}$ (sebelum pemanasan) dan 52,34;303,16 dan 497,34 HV (setelah pemanasan). Dari ketiga sampel uji diperoleh kekerasan paling besar pada zona antarmuka sampel diffusion couple $\mathrm{U}-7 \mathrm{Mo} / \mathrm{Al}$ dengan pelat AlMg2, bila dibandingkan dengan kelongsong AIMg2 dan juga paduan U-7Mo. Perbedaan kekerasan ini menunjukkan bahwa pada pengujian interdifusi menggunakan metode diffusion couple menghasilkan senyawa baru (U,Mo)Alx pada zona antarmuka yang memiliki karakter berbeda. Terbentuknya interaction layer tidak diharapkan dalam bahan bakar dispersi U-Mo/Al karena layer senyawa (U,Mo)Al memiliki kekerasan mikro dan densitas lebih rendah dari pada densitas rata-rata paduan bahan bakar U-7Mo/Al.

Kata kunci: U-7Mo/Al, diffusion couple, interaction layer, mikrostruktur, DTA dan kekerasan mikro. 


\section{ABSTRACT}

TEMPERATURE AND IRRADIATION EFFECTS TO INTERDIFUSSION OF FUEL MATERIAL U-7Mo/AI TYPE. U-7Mo/Al alloy had great potential as research reactor fuel, but it had several disadvantages, such as, it can formed a interaction layer at the interface during the process of fabrication and irradiation in a reactor. The research objective was determine the interaction layer that was caused by interdiffusion or diffusion couple of U-7Mo with AIMg2 alloy which was annealed at $500{ }^{\circ} \mathrm{C}$ and $550^{\circ} \mathrm{C}$ for 24 hours. The observation of microstructure used a Scanning Electron Microscope (SEM) on diffusion couple sample which was heated at temperature of $500^{\circ} \mathrm{C}$ had not seen the layer interaction or the formation of a new phase between particles of $\mathrm{U}-\mathrm{Mo}$ and $\mathrm{Al}$ matrix, but heating treatment at $550{ }^{\circ} \mathrm{C}$ indicated that U-7Mo alloy had been interdiffusion with $A I M g 2$ plate produced $(U, M O)$ Alx compound on the interfaces. It was evidenced by interdiffusion reaction analysis used DTA that showed that U-7Mo / Al alloy at $500^{\circ} \mathrm{C}$ had good heat compactibility, but at temperatures upper than $550^{\circ} \mathrm{C}$ it had been phase changed from $\alpha+\delta$ to $\alpha+\gamma$ phase. The heating in DTA furnace up to $679.14{ }^{\circ} \mathrm{C}$ produced $U(A l, M o) x$ meta stable phase and then interdiffusion process with uranium molten formed layer interaction that formed UAlx compound agglomerates (UAI4, UAl3 and UAI2). Agglomerates was formed from the heating process which was similar to agglomerates that caused by irradiation. U-7Mo / Al Fuel alloy that had 58\% burn up had been interdiffusion between U-7Mo with Al matrix produced $U(A l, M o) x$ metastable phase that turned into (U, Mo) $A l_{7}$ layer, $U \mathrm{Mo}_{2} \mathrm{Al}_{20}$ precipitates, (UMo)Al $l_{3}-A l$ and formed a boundary or $\cup A I x\left(U A l_{4}, \cup A l_{3}\right.$ and $\left.\cup A l_{2}\right)$ agglomerates. The results of microstructure analysis used SEM and interdiffusion reactions used DTA was supported by the analysis of micro hardness used Vickers Hardness. The results of hardness analysis that was done to AIMg cladding and U-7Mo alloy (before and after heating) and diffusion couple of $\mathrm{U}-7 \mathrm{Mo}$ / Al samples with AIMg2 plate after heating at $550{ }^{\circ} \mathrm{C}$ were respectively 64.62 and 340.45 HV (before heating) and 52.34; 303.16 and 497.34 HV (after heating). Diffusion couple $U-7 \mathrm{Mo} / \mathrm{Al}$ with AlMg2 plate samples had the highest hardness value. This hardness difference showed that the interdiffusion test used diffusion couple produced a new compound (U, Mo) Alx in interface zone that had different character, but the formation of interaction layer is not expected in the fuel U-Mo / Al dispersion because micro hardness and density of (U, Mo) Alx compound's layer was lower than the average density of $U-7 \mathrm{Mo} / \mathrm{Al}$ alloy.

Keywords: U-7Mo/Al, diffusion couple, interaction layer, microstructure, DTA and micro hardness. 


\section{PENDAHULUAN}

Reaktor Serba Guna G.A. Siwabessy (RSG-GAS) yang berada di Serpong merupakan reaktor riset jenis Material Testing Reactor (MTR) yang berfungsi antara lain untuk memproduksi radiofarmaka untuk kebutuhan rumah sakit dan pengujian material. Berdasarkan desain awal, reaktor ini dioperasikan menggunakan bahan bakar dispersi $\mathrm{U}_{3} \mathrm{O}_{8}-\mathrm{Al}$ dengan pengayaan (low enrichement) uranium $19,75 \%{ }^{235} \mathrm{U}$. Keberhasilan penelitian dan pengembangan bahan bakar $\mathrm{U}_{3} \mathrm{Si}_{2} / \mathrm{Al}$ di BATAN, maka sejak tahun 2001 semua bahan bakar diteras reaktor RSG-GAS telah berhasil digantikan oleh bahan bakar $\mathrm{U}_{3} \mathrm{Si}_{2} / \mathrm{Al}$ dengan pengayaan dan densitas uranium yang sama seperti bahan bakar $\mathrm{U}_{3} \mathrm{O}_{8}-\mathrm{Al}$. Bahan bakar dispersi $\mathrm{U}_{3} \mathrm{Si}_{2} / \mathrm{Al}$ dibuat dengan cara memadukan uranium dengan unsur silikon menjadi senyawa $\mathrm{U}_{3} \mathrm{Si}_{2}$ dan didispersikan ke dalam serbuk matrikss aluminium (Al). Bahan bakar $\mathrm{U}_{3} \mathrm{Si}_{2} / \mathrm{Al}$ ini memiliki stabilitas yang tinggi selama digunakan sebagai bahan bakar di dalam reaktor, akan tetapi memiliki beberapa kekurangan yaitu densitas uranium yang dapat dicapai maksimum hanya sekitar $4,8 \mathrm{gU} / \mathrm{cm}^{3}$ yang menyebabkan umur pakai lebih pendek, dan olah ulang bahan bakar $\mathrm{U}_{3} \mathrm{Si}_{2} / \mathrm{Al}$ sangat sulit, sehingga menjadi masalah dalam proses penyimpanan. Mengingat hal tersebut, para peneliti berupaya untuk mencari paduan uranium dengan logam lain yang memiliki densitas uranium tinggi, sehingga umur ekonomi bahan bakar di dalam teras reaktor dan siklus penggunaan bahan bakar menjadi lebih lama. Penelitian dan pengembangan bahan bakar reaktor riset berbasis U-Mo dengan pengayaan uranium ${ }^{235} \mathrm{U}<20 \%$ merupakan program internasional dalam memenuhi densitas uranium antara 8 $9 \mathrm{gU} / \mathrm{cm}^{3[1]}$.

Paduan U-Mo merupakan sistem biner dengan diagram fasa seperti yang ditunjukkan pada Gambar 1[2]. Paduan
U-Mo bersifat ulet dan memiliki struktur kristal bcc fasa $\gamma$, tampang lintang serapan neutron Mo rendah, tahan terhadap korosi dan berat jenis $\pm 16,4 \mathrm{~g} / \mathrm{cm}^{3}$ serta nilai berat jenis tergantung \% Mo. Berat jenis tersebut lebih tinggi dari berat jenis paduan $\mathrm{U}_{3} \mathrm{Si}_{2}$ sebesar $12,20 \mathrm{~g} / \mathrm{cm}^{3}$ yang telah digunakan sebagai bahan bakar dispersi dengan tingkat muat uranium $4,80 \mathrm{gU} / \mathrm{cm}^{3}$. Paduan U-Mo dapat digunakan sebagai bahan bakar dengan tingkat muat uranium hingga $9 \mathrm{~g} / \mathrm{cm}^{3}$ dan proses olah ulang mudah dilakukan [2]. Selain itu Mo memiliki tampang lintang serapan neutron relatif rendah dan paduan U-7Mo/Al mempunyai daerah fasa gamma $(\gamma)$ relatif besar dan dapat dipertahankan selama proses fabrikasi bahan bakar dan iradiasi, memiliki kompatibilitas termal baik dengan matriks $\mathrm{Al}$ sehingga paduan U-Mo cocok untuk digunakan sebagai bahan bakar reaktor riset sekaligus sebagai pengganti bahan bakar $\mathrm{U}_{3} \mathrm{O}_{8} / \mathrm{Al}$ dan $\mathrm{U}_{3} \mathrm{Si}_{2} / \mathrm{Al}$.

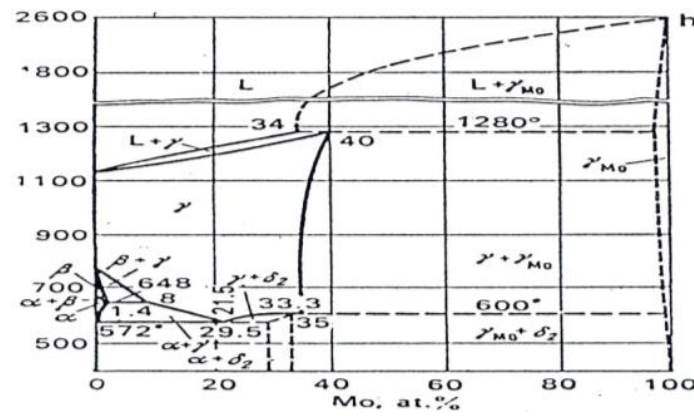

Gambar 1. Diagram Fasa Paduan U-Mo[2]

Peneliti sebelumnya telah berhasil membuat pelat elemen bakar (PEB) $\mathrm{U}-7 \mathrm{Mo} / \mathrm{Al}$ dengan berukuran mini[2]. Berdasarkan informasi perkembangan ilmiah saat ini paduan U-Mo dengan kandungan Mo antara 7 10\% berat, memiliki prospek yang sangat baik untuk digunakan sebagai bahan bakar nuklir dispersi dengan pengayaan uranium rendah karena mempunyai densitas sekitar $18,6 \mathrm{~g} / \mathrm{cm}^{3}$ bila dibanding dengan densitas bahan bakar $\mathrm{U}_{3} \mathrm{Si}_{2}$ hanya sekitar $12,2 \mathrm{~g} / \mathrm{cm}^{3}$, sehingga paduan U-Mo tersebut dengan mudah dapat dibuat menjadi elemen bakar nuklir dengan tingkat muat uranium lebih besar dari $8-9 \mathrm{gU} / \mathrm{cm}^{3}$. 
Keunggulan yang dimiliki oleh paduan U-Mo tersebut membuat paduan U-Mo merupakan salah satu kandidat bahan bakar reaktor riset yang sedang trend di dunia untuk dipelajari dan dilakukan penelitian dan pengembangan teknologi fabrikasinya maupun penggu-naannya sebagai bahan bakar di dalam reaktor ${ }^{[2]}$.

Proses pembuatan paduan $\mathrm{U}-7 \mathrm{Mo} / \mathrm{Al}$ dilakukan dengan menggunakan teknik peleburan tungku busur listrik (arc furnace). Kadar uranium digunakan sebagai dasar untuk perhitungan penyiapan komposisi paduan. Sebelum paduan U-Mo dibuat, permukaan logam $U$ dibersihkan dengan asam nitrat beberapa saat hingga unsur logam pengotor yang menempel di permukaan terlepas kemudian dinetralkan dan dibilas menggunakan air bebas mineral. Logam $U$ dibilas dengan alkohol dan dikeringkan dalam udara terbuka. Pembuatan porsi paduan U-7Mo/AI dilakukan dengan penimbangan logam-logam berdasarkan kepada perhitungan persen berat unsur logam pemadu dan matriks Al dalam komposisi paduan.

Paduan $\mathrm{U}-7 \mathrm{Mo} / \mathrm{Al}$ dengan fasa $\gamma-\mathrm{U}$ memiliki kestabilan dan unjuk kerja yang baik selama iradiasi, akan tetapi terbentuk reaksi difusi pada antarmuka U-7Mo dengan matriks Al selama proses fabrikasi maupun dalam proses iradiasi di reaktor. Dalam proses fabrikasi pembuatan bahan bakar U-7Mo, serbuk U-Mo didispersikan dengan matriks $\mathrm{Al}$, dimana matriks $\mathrm{Al}$ berfungsi sebagai penghantar panas dalam bahan bakar serta berfungsi untuk mengisi kekosongan porositas yang terdistribusi didalam bahan bakar $\mathrm{U}-7 \mathrm{Mo}^{[2]}$. Distribusi matriks Al yang merata di dalam bahan bakar U-Mo menyebabkan tidak terjadinya pengelembungan bahan bakar sewaktu digunakan di dalam reaktor. Begitu pentingnya kegunaan matriks Al di dalam bahan bakar U-7Mo maka perlu dipahami dan diketahui fenomena yang terjadi akibat interdifusi matriks Al ke dalam partikel U-Mo, karena fenomena tersebut dapat menyebabkan perubahan karakter bahan bakar U-7Mo/Al.

Pada kegiatan ini akan dipelajari pengaruh iradiasi dan temperatur terhadap interdifusi partikel bahan bakar U-7Mo/Al dengan tujuan untuk mengetahui perubahan unjuk kerja atau karakteristik bahan bakar dari U-7Mo/Al yang disebabkan oleh pemanasan maupun iradiasi di reaktor. Sifat atau karakteristik dari bahan bakar paduan U-7Mo/Al yang akan dipelajari pada penelitian ini adalah kompatibilitas panas paduan $\mathrm{U}-7 \mathrm{Mo} / \mathrm{Al}$, interaksi $\mathrm{U}-7 \mathrm{Mo}$ dengan matriks Al serta terjadinya perubahan fasa atau pembentukan fasa baru yang disebabkan oleh pemanasan maupun iradiasi.

\section{METODOLOGI}

Paduan U-7Mo/Al dan bahan kelongsong AlMg2 dipotong masing-masing dengan ukuran $5 \times 5 \times 2 \mathrm{~mm}$. Kedua bahan tersebut dikenakan proses metalografi meliputi pengamplasan dari ukuran grit 500 hingga grit 2400 , selanjutnya dilakukan pemolesan dengan pasta intan dari ukuran 3 sampai 1 mikron. Sampel paduan U-7Mo/AI dan kelongsong AIMg2 yang telah dipoles, kemudian diklem atau dikontakkan permukaannya satu sama lain dengan tingkat kekencangan tertentu ${ }^{[3]}$. Metode percobaan seperti ini disebut dengan diffusion couple atau klem seperti yang ditunjukkan pada Gambar 2.

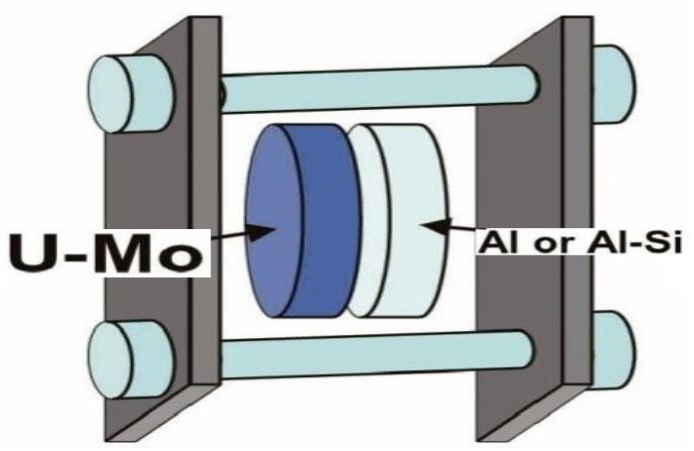

Gambar 2. Skema alat diffusion couple ${ }^{[3]}$ 
Hasil proses diffusion couple paduan $\mathrm{U}-7 \mathrm{Mo} / \mathrm{Al}$ dengan pelat AIMg2 dipanaskan dalam tungku arc furnace pada temperatur $500{ }^{\circ} \mathrm{C}$ dan $550{ }^{\circ} \mathrm{C}$ selama 24 jam. Sampel hasil pemanasan kemudian dianalisis mikrostruktur yang terjadi yaitu terjadinya interdifusi $\mathrm{U}-7 \mathrm{Mo} / \mathrm{Al}$ dengan AIMg2 menggunakan SEM (Scanning Electron Microscope) dan kekerasan mikro menggunakan Hardness Vickers dengan beban $200 \mathrm{gF}$. Selain mikrostruktur dan kekerasan mikro, pada penelitian ini juga dilakukan analisis pengaruh temperatur terhadap kompatibilitas panas dari paduan $\mathrm{U}-7 \mathrm{Mo} / \mathrm{Al}$, interaksi U-7Mo dengan matriks Al dan perubahan fasa atau pembentukan fasa baru yang dianalisis menggunakan Differential Thermal Analysis (DTA). Paduan $\mathrm{U}-7 \mathrm{Mo} / \mathrm{Al}$ ditimbang dengan berat $185 \mathrm{mg}$, kemudian dimasukkan ke dalam krusibel alumina dan diletakkan di dalam chamber DTA rod untuk divakumkan hingga tekanan $10^{-1}$ bar. Setelah tercapai kondisi vakum, chamber DTA rod dialiri gas argon dengan tekanan 2,5 bar. Analisis perubahan fasa paduan $\mathrm{U}-7 \mathrm{Mo} / \mathrm{Al}$ dilakukan mulai dari temperatur $30{ }^{\circ} \mathrm{C}$ hingga $1400{ }^{\circ} \mathrm{C}$ dengan kecepatan pemanasan $10{ }^{\circ} \mathrm{C} /$ menit (setiap sampel dilakukan 2 kali pengulangan pengukuran). Hasil analisis berupa termo-gram DTA kemudian dievaluasi untuk mengetahui kompatibilitas panas dari paduan $\mathrm{U}-\mathrm{Mo} / \mathrm{Al}$, interaksi, U-Mo dengan matriks Al dan perubahan fasa. Untuk membuktikan adanya interaksi U-7Mo dengan matriks $\mathrm{Al}$ dan perubahan fasa atau terjadinya pembentukan fasa baru, paduan U-Mo/Al hasil pemanasan dalam tungku DTA dilakukan juga analisis mikrostruktur dengan menggunakan SEM untuk selanjutnya dibandingkan dengan hasil pemanasan dengan tungku arc furnace.

Dalam usaha untuk mengetahui pengaruh iradiasi terhadap proses interdifusi paduan $\mathrm{U}-7 \mathrm{Mo}$ dengan matriks $\mathrm{Al}$, maka dilakukan metode kajian dari beberapa pustaka. Proses interdifusi paduan U-7Mo dengan matriks $\mathrm{Al}$ maupun kelongsong
AIMg2 hasil pemanasan dalam tungku arc furnace maupun DTA dibandingkan dengan hasil interdifusi yang disebabkan oleh iradiasi di reaktor.

\section{HASIL DAN PEMBAHASAN}

\section{a. Analisis mikrostruktur}

Mikrostruktur dari sampel diffusion couple U-7Mo/Al dengan pelat AlMg2 hasil pemanasan pada temperatur $500{ }^{\circ} \mathrm{C}$ selama 24 jam dan dianalisis menggunakan SEM dengan pembesaran 2500 dan 5000 kali ditunjukkan pada Gambar 3.
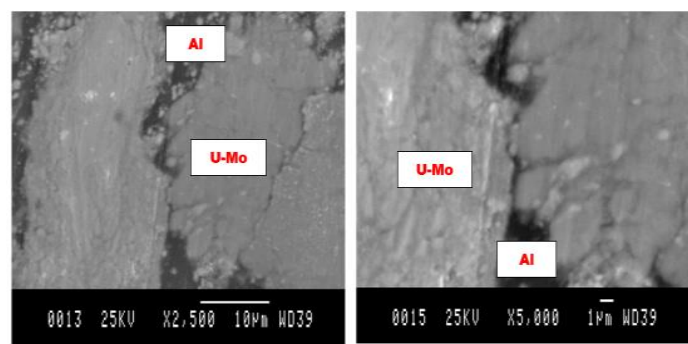

Gambar 3. Mikrostruktur paduan U-7Mo/Al hasil pemanasan pada $500^{\circ} \mathrm{C}$ selama 24 jam

Gambar 3 menunjukkan bahwa mikrostruktur yang berwarna lebih terang adalah paduan $\mathrm{U}-7 \mathrm{Mo}$, sedangkan daerah yang lebih gelap (abu-abu gelap) adalah matriks Al. Mikrostruktur paduan U-7Mo dengan perbesaran 2500 dan 5000 kali terlihat adanya retakan pada paduan U-7Mo. Hal ini disebabkan oleh proses pengerolan pada saat fabrikasi, tetapi pada daerah antarmuka tidak terlihat adanya fasa baru atau interaction layer antara partikel U-Mo dan matriks Al. Hal ini disebabkan oleh beberapa faktor diantaranya adalah intensitas kontak serta luas permukaan kontak yang kurang maksimal antara paduan U-Mo dengan matriks Al serta temperatur pemanasan $500{ }^{\circ} \mathrm{C}$ belum cukup energi dalam (laten heat) yang dibutuhkan untuk terjadinya proses interdifusi. Hal ini dibuktikan dengan analisis kompatibilitas panas paduan $\mathrm{U}-7 \mathrm{Mo} / \mathrm{Al}$ menggunakan DTA yang menunjukkan bahwa paduan $\mathrm{U}-7 \mathrm{Mo} / \mathrm{Al}$ pada temperatur $500{ }^{\circ} \mathrm{C}$ tidak 
terjadi perubahan base line aliran panas pada termogram DTA.

Mikrostruktur dari sampel diffusion couple $\mathrm{U}-7 \mathrm{Mo} / \mathrm{Al}$ dengan pelat $\mathrm{AlMg} 2$ hasil pemanasan pada temperatur $550{ }^{\circ} \mathrm{C}$ selama 24 jam yang dianalisis menggunakan SEM ditunjukkan pada Gambar 4.

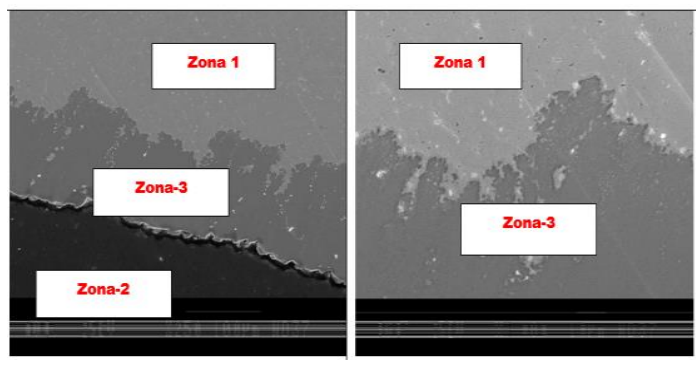

Gambar 4. Mikrostruktur interaction layer paduan $\mathrm{U}-7 \mathrm{Mo}$ dengan pelat AlMg2

Gambar 4 menunjukkan bahwa mikrostruktur yang dihasilkan terdiri dari tiga bagian atau zona. Pada zona-1 diperoleh struktur dengan warna abu-abu terang adalah paduan $\mathrm{U}-7 \mathrm{Mo}$, zona-2 berwarna gelap diduga adalah bahan AIMg2, sedangkan pada antarmuka menghasilkan struktur dengan warna lebih gelap dibanding U-7Mo dan lebih terang dibanding logam AlMg2 yang terjadi pada zona-3. Struktur baru pada antarmuka yaitu interaction layer merupakan lapisan hasil interdifusi antara paduan U-7Mo dengan pelat AIMg2. Layer yang dihasilkan pada zona antarmuka diduga adalah senyawa (U,Mo)Al $\mathrm{I}_{x}$ dengan ketebalan relatif bervariasi antara 93,6 hingga 133,0 mikron atau dengan rata-rata sekitar 115,4 mikron. Senyawa (U,Mo)Alx yang terbentuk harus dibuktikan lebih lanjut dengan pengujian Energy Dispersive Analysis (EDS) dan X-Ray Difraktometer (XRD). Analisis interdifusi dari bahan bakar $\mathrm{U}-\mathrm{Mo} / \mathrm{Al}$ dengan metode diffusion couple dapat digunakan untuk mengetahui sejauh mana kestabilan bahan bakar akibat pemanasan maupun iradiasi. Terbentuknya interaction layer tidak diharapkan dalam bahan bakar dispersi U-Mo/Al karena layer senyawa $(\mathrm{U}, \mathrm{Mo}) \mathrm{Al} \times \mathrm{m}$ memiliki densitas lebih rendah daripada densitas rata-rata paduan
$\mathrm{U}-7 \mathrm{Mo} / \mathrm{Al}$, sehingga pertumbuhan layer dapat menyebabkan swelling inti elemen bahan bakar yang cukup signifikan ${ }^{[4]}$.

Hasil interdifusi menggunakan diffusion couple dibandingkan dengan hasil interdifusi menggunakan DTA. Hasil analisis interdifusi dengan DTA pada temperatur $30^{\circ} \mathrm{C}$ sampai $1400^{\circ} \mathrm{C}^{[5]}$ menunjukkan bahwa paduan $\mathrm{U}-7 \mathrm{Mo}$ mempunyai kompa-tibilitas panas yang baik dengan matriks Al hingga temperatur pemanasan $500{ }^{\circ} \mathrm{C}$ seperti yang ditunjukkan pada Gambar 5.

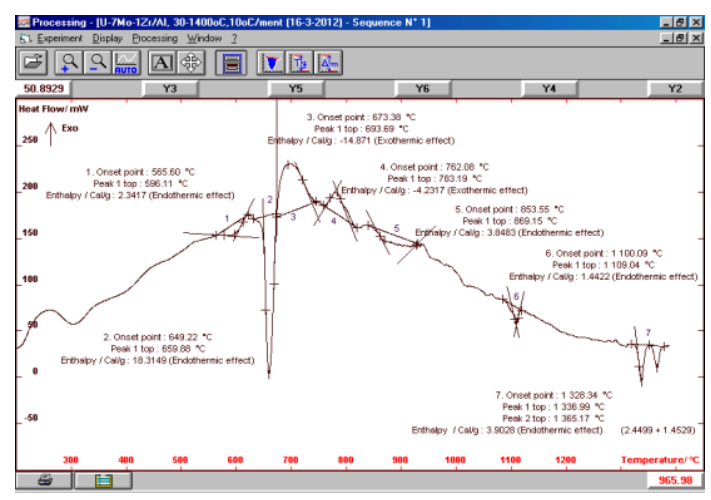

Gambar 5. Termogram DTA kompatibilitas matriks Al dengan $\mathrm{U}-7 \mathrm{Mo}^{[6,7]}$

Pada temperatur $580,16{ }^{\circ} \mathrm{C}$ paduan $\mathrm{U}-7$ Mo telah mengalami perubahan fasa dari fasa $\alpha+\delta$ menjadi fasa $\alpha+\gamma^{[6,7]}$. Perubahan fasa ini ditunjukkan dengan adanya perubahan base line aliran panas dari pengukuran pada temperatur $580,16{ }^{\circ} \mathrm{C}$ seperti yang terlihat pada puncak-1 Gambar 5. Perubahan fasa yang terjadi pada temperatur $580,16{ }^{\circ} \mathrm{C}$ tidak menye-babkan interaksi matriks $\mathrm{Al}$ dengan bahan bakar U-7Mo. Hal ini dibuktikan dengan hasil penelitian sebelumnya yaitu analisis termal serbuk Al 99,99\% dan Mo ${ }^{[6,7]}$. Pada penelitian sebelumnya telah diketahui bahwa aliran panas (heat flow) untuk serbuk Al $99,99 \%$ mulai berubah pada temperatur $660,52{ }^{\circ} \mathrm{C}$, sedangkan aliran panas bahan bakar Mo telah berubah pada temperatur $578,63 \quad{ }^{\circ} \mathrm{C}$. Gambar 5 puncak-2 menunjuk-kan bahwa pada temperatur $630,37^{\circ} \mathrm{C}$ hingga $661,28^{\circ} \mathrm{C}$ paduan $\mathrm{U}-7 \mathrm{Mo}$ mengalami reaksi peleburan matriks $\mathrm{Al}$, fenomena peleburan matriks $\mathrm{Al}$ ini 
diindikasikan dengan terjadinya reaksi endotermik pada onset temperatur $630,37^{\circ} \mathrm{C}$ dan berakhir pada top temperatur $661,28^{\circ} \mathrm{C}$. Reaksi tersebut menunjukkan matriks Al di dalam $\mathrm{U}-7$ Mo mulai melebur pada temperatur $630,37{ }^{\circ} \mathrm{C}$ dan berakhir melebur pada temperatur $661,28{ }^{\circ} \mathrm{C}$ dengan membutuhkan panas (entalpi) sebesar $\Delta \mathrm{H}=132,85 \mathrm{~J} / \mathrm{g}$. Reaksi peleburan matriks Al pada Gambar 5 puncak-2 sama dengan fenomena reaksi peleburan serbuk $A[[6,7]$.

Pemanasan paduan U-7Mo/Al pada temperatur $630,37{ }^{\circ} \mathrm{C}$ hingga $679,14{ }^{\circ} \mathrm{C}$, telah terjadinya interdifusi $\mathrm{U}-7 \mathrm{Mo}$ dengan lelehan matriks $\mathrm{Al}$ yang menyebabkan pembentukan fasa baru. Hal ini dibuktikan dengan hasil analisis mikrostruktur paduan $\mathrm{U}-7 \mathrm{Mo} / \mathrm{Al}$ menggunakaan SEM seperti yang terlihat pada Gambar 6 .

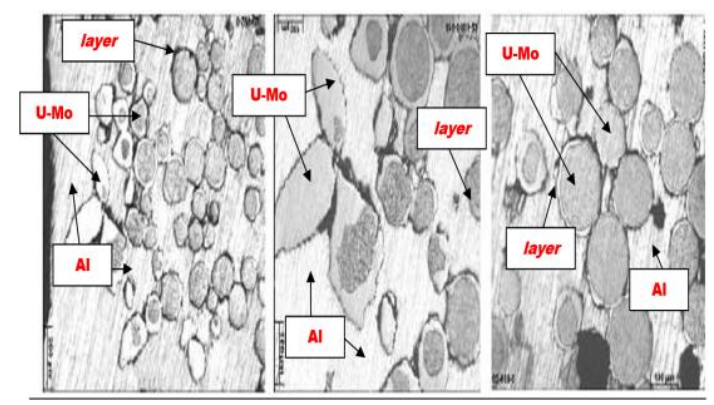

Gambar 6. Mikrostruktur U-7Mo/Al pada pemanasan $630^{\circ} \mathrm{C}[8]$

Gambar 6 menunjukkan bahwa proses pemanasan pada temperatur $630^{\circ} \mathrm{C}$ selama 4 jam telah terjadi pembentukan fasa metastabil U(Al,Mo)× dan menyebabkan terjadinya interaction layer antara partikel paduan U-7Mo dengan lelehan matriks $\mathrm{Al}$ pada temperatur $679,14^{\circ} \mathrm{C}$. Hasil identifikasi fasa menggunakan difraksi sinar-X (XRD) menunjukkan hasil bahwa telah terjadi pembentukan fasa baru layer (U,Mo)Al presipitat $\mathrm{UMo}_{2} \mathrm{Al}_{20}$ dan (UMo) $\mathrm{Al}_{3}-\mathrm{Al}$ boundary[8]. Pembentukan fasa ini terjadi disebabkan oleh beberapa faktor diantaranya adalah intensitas kontak atau luas permukaan kontak antara lelehan matriks Al yang besar, sehingga lelehan matriks $\mathrm{Al}$ berdifusi dan membungkus partikel U-7Mo membentuk boundary atau aglomerat ${ }^{[8,9]}$. Aglomerat yang terbentuk adalah senyawa $\mathrm{UAl}_{x}\left(\mathrm{UAl}_{4}, \mathrm{UAl}_{3}\right.$ dan $\left.\mathrm{UAl}_{2}\right)$ dan senyawa $U$-Mo seperti yang ditunjukkan pada Gambar 6.

Pemanasan lebih lanjut terhadap paduan U-7Mo hingga temperatur 719,20 ${ }^{\circ} \mathrm{C}$ ditunjukkan pada Gambar 5 puncak-3, terlihat jelas bahwa hasil leburan matriks $\mathrm{Al}$ secara langsung bereaksi dengan bahan bakar U-Mo membentuk senyawa $\mathrm{U}(\mathrm{Al}, \mathrm{Mo})_{x}{ }^{[10]}$. Reaksi pembentukan senyawa $\mathrm{U}(\mathrm{Al}, \mathrm{Mo})_{x}$ ditunjukkan dengan terjadinya reaksi eksotermik secara cepat setelah terjadi reaksi peleburan matriks Al. Reaksi eksotermik pada puncak-3 terjadi berdekatan dengan puncak endotermik peleburan matriks Al yang terjadi pada puncak-2. Hal ini disebabkan karena difusi lelehan martik Al ke dalam bahan bakar UMo secara cepat. Selain itu, juga disebabkan karena lelehan matriks Al mempunyai kontak antarmuka dengan gaya gerak yang lebih besar sehingga ikatan intermetalik lelehan Al dengan UMo terjadi secara simultan dengan reaksi peleburan matriks A[[6,7]. Pembentukan senyawa $\mathrm{U}(\mathrm{Al}, \mathrm{Mo}) \mathrm{x}$ pada reaksi eksotermik tersebut menunjukkan bahwa pemanasan hingga temperatur 719,20 ${ }^{\circ} \mathrm{C}$ terbentuk dua senyawa UAlx dan UMo dalam kondisi metastabil[6,7]. Gambar 5, pada puncak-6 menunjukkan bahwa pada temperatur $1100,09{ }^{\circ} \mathrm{C}$ hingga $1109,04{ }^{\circ} \mathrm{C}$ terlihat jelas adanya reaksi endotermik yang menun-jukkan terjadinya proses peleburan logam uranium. Senyawa metastabil $\mathrm{U}(\mathrm{Al}, \mathrm{Mo}) \times$ yang terbentuk sebelumnya pada puncak 5 secara langsung bereaksi dengan leburan uranium membentuk senyawa $\mathrm{U}(\mathrm{Al}, \mathrm{Mo})_{\times}$yang stabil. Pemanasan lebih lanjut hingga temperatur $1328,34{ }^{\circ} \mathrm{C}$ sampai dengan $1365,17^{\circ} \mathrm{C}$ terjadi reaksi endotermik yang menunjukkan terjadinya reaksi peruraian atau reaksi dekomposisi $\mathrm{U}(\mathrm{Al}, \mathrm{Mo})_{x}$ menjadi senyawa $U A I_{x}\left(U A I_{4}, U A I_{3}\right.$ dan $\left.U A I_{2}\right)$ dan senyawa U-Mo seperti yang terlihat pada puncak-7 pada Gambar 5[10,11]. Besarnya pembentukan senyawa tersebut harus dilakukan identifikasi lebih lanjut 
dengan menggunakan $X$-Ray difraktometer (XRD).

Reaksi interdifusi pada bahan bakar $\mathrm{U}-7 \mathrm{Mo} / \mathrm{Al}$ yang disebabkan pemanasan terjadi dengan tahapan reaksi sebagai berikut:[6,7,10,11,12]

$\mathrm{U}-7 \mathrm{Mo}+\mathrm{Al}$ (padat) $\rightarrow \mathrm{U}-7 \mathrm{Mo}+\mathrm{Al}$ (padat) (perubahan fasa pada, $550^{\circ} \mathrm{C}$ )

$\mathrm{U}-7 \mathrm{Mo}+\mathrm{Al}$ (padat) $\rightarrow \mathrm{U}-7 \mathrm{Mo}+\mathrm{Al}$ (liq)

(peleburan matriks $\mathrm{Al}, 630,37^{\circ} \mathrm{C}$ )

$\mathrm{U}-7 \mathrm{Mo}+\mathrm{Al}(\mathrm{liq}) \rightarrow \mathrm{UMo}+\mathrm{U}(\mathrm{Al}, \mathrm{Mo})_{\mathrm{x}}$ (terbentuk fasa metastabil, $679,14^{\circ} \mathrm{C}$ )

$\mathrm{U}-7 \mathrm{Mo}+\mathrm{U}(\mathrm{Al}, \mathrm{Mo})_{x} \rightarrow \mathrm{UAl} \mathrm{l}_{\mathrm{x}} \mathrm{U}-\mathrm{Mo} \times$ (peleburan uranium pada $1109,04^{\circ} \mathrm{C}$ )

Dari reaksi interdifusi paduan U-7Mo dengan matriks Al menunjukkan bahwa pemanasan hingga $500{ }^{\circ} \mathrm{C}$, paduan bahan bakar U-7Mo/Al mempunyai kompatibilitas panas yang baik ${ }^{[6,7]}$ dan dibuktikan dengan analisis mikrostruktur paduan U-Mo/Al pada temperatur pemanasan $500{ }^{\circ} \mathrm{C}$ dengan waktu pemanasan selama 20 jam menggunakan SEM seperti yang ditunjukkan pada Gambar 3 , diketahui bahwa belum terjadi interdifusi antara U-7Mo dengan matriks Al.

Proses interdifusi paduan U-7Mo dengan matriks $\mathrm{Al}$ yang disebabkan oleh pemanasan hampir sama dengan proses interdifusi paduan $\mathrm{U}-7 \mathrm{Mo}$ dengan matriks $\mathrm{Al}$ yang disebabkan oleh iradiasi di reaktor. Analisis interdifusi paduan $\mathrm{U}-7 \mathrm{Mo} / \mathrm{Al}$ yang disebabkan oleh radiasi belum dapat dilakukan di Instalasi Radiometalurgi PTBBN, karena bahan bakar pelat mini paduan $\mathrm{U}-7 \mathrm{Mo} / \mathrm{Al}$ yang telah difabrikasi belum dilakukan proses iradiasi di reaktor. Analisis interdifusi paduan U-7Mo dengan matriks Al akibat proses iradiasi dipelajari berdasarkan kajian dari hasil peneliti sebelumnya ${ }^{[14,15]}$.

Penampilan pelat elemen bakar (PEB) tipe $\mathrm{U}-7 \mathrm{Mo} / \mathrm{Al}$ sebelum di radiasi ditunjukkan pada Gambar 7. Bahan bakar PEB U-7Mo/Al selama berada di dalam reaktor, dapat digunakan sebagai bahan bakar hingga burn up tertentu. RSG-GAS biasanya dioperasikan hingga burn up 56\% (persyaratan dari BAPETEN dan IAEA) dan mengalami beberapa jenis pembebanan diantaranya adalah flux neutron dan temperatur. Fluk neutron yang diterima bahan bakar sebesar $131,1 \mathrm{~W} / \mathrm{cm}^{3}$ dan temperatur yang diterima pada bagian inti bahan bakar dan antarmuka inti elemen bakar dengan kelongsong lebih dari $170^{\circ} \mathrm{C}$. Peningkatan distribusi temperatur di dalam bahan bakar rata-rata sebesar $120{ }^{\circ} \mathrm{C}$ menjadi $170{ }^{\circ} \mathrm{C}$, hal ini menyebabkan terjadinya hot spot pada posisi tertentu di dalam bahan bakar ${ }^{[13]}$.

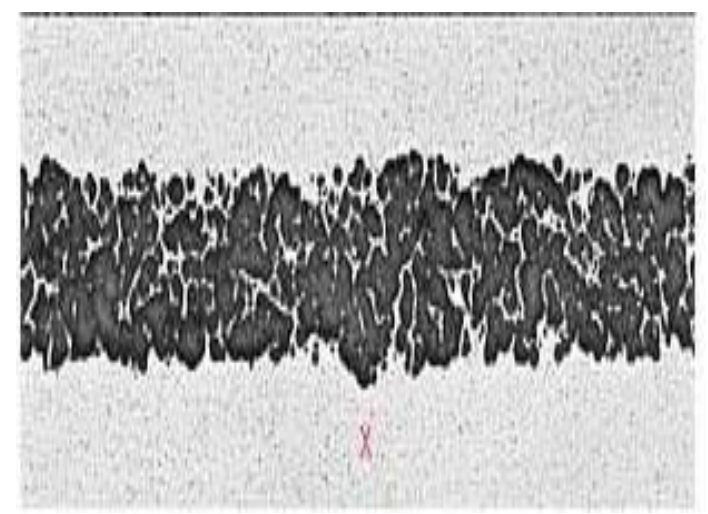

Gambar 7. Mikrostruktur PEB U-7Mo/AI sebelum diradiasi[11]

Peningkatan distribusi temperatur disebabkan oleh radiasi yang terkorelasi dengan lamanya bahan bakar di dalam reaktor dengan burn up tertentu sehingga kandungan hasil fisi dan unsur bermassa berat (heavy element, HE) dalam bahan bakar meningkat. Fenomena ini terjadi karena adanya reaksi fisi ${ }^{235} \mathrm{U}$ dengan neutron di dalam teras reaktor dengan burn up tertentu sesuai dengan persyaratan pengoperasian reaktor.

Bahan bakar paduan U-7Mo/AI pasca iradiasi dianalisis mikrostruktur, khususnya interdifusi U-7Mo dengan matriks Al. Perubahan mikrostruktur bahan bakar paduan $\mathrm{U}-7 \mathrm{Mo} / \mathrm{Al}$ setelah mengalami iradiasi dengan burn up 58\% ditunjukkan pada Gambar 8[14,15].

Gambar 8 menunjukkan bahwa bahan bakar U-7Mo/Al yang telah diiradiasi di reaktor dengan burn up 58\% mengalami 
interdifusi antara U-7Mo dengan matriks Al. Interdifusi antara $\mathrm{U}-7 \mathrm{Mo}$ dengan matriks $\mathrm{Al}$ yang disebabkan oleh iradiasi menghasilkan fasa yang sama dengan proses pemanasan yaitu fasa metastabil $\mathrm{U}(\mathrm{Al}, \mathrm{Mo})_{3}$ yang berubah menjadi layer $(\mathrm{U}, \mathrm{Mo}) \mathrm{A} \mathrm{I}_{7}$, presipitat $\mathrm{UMo}_{2} \mathrm{Al}_{20}, \quad(\mathrm{UMo}) \mathrm{Al}_{3}-\mathrm{Al}, \mathrm{U}(\mathrm{Al}, 0,9 \mathrm{Mo}) \mathrm{Al}_{4}$ dan membentuk boundary atau aglomerat senyawa $\cup A l_{x}\left(U A l_{4}, \cup A l_{3} \text { danUAl }\right)^{[10,14,15,16]}$.

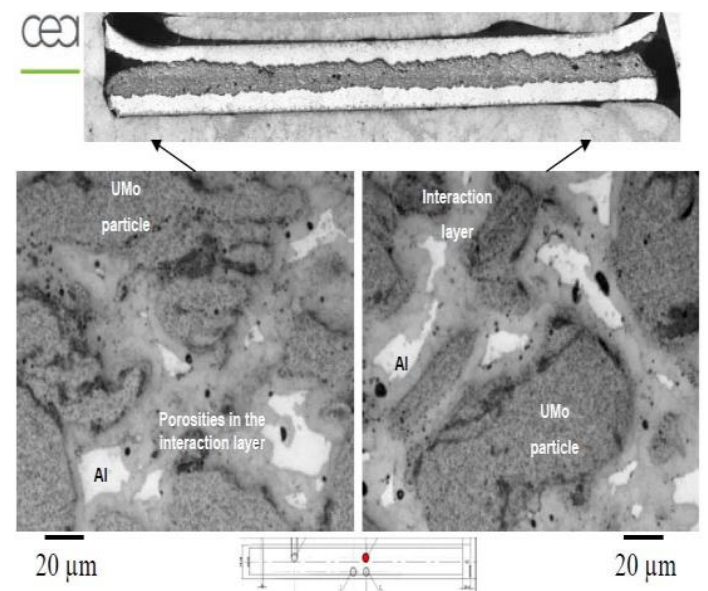

Gambar 8. Struktur mikro bahan bakar $\mathrm{U}-7 \mathrm{Mo} / \mathrm{Al}$ dengan burn up $58 \%[14,15$

\section{b. Analisis kekerasan mikro}

Pengujian kekerasan mikro dilakukan terhadap paduan $\mathrm{U}-7 \mathrm{Mo}$, pelat AlMg2 segar (tanpa pemanasan) dan terhadap sampel paduan $\mathrm{U}-7 \mathrm{Mo}$, pelat AlMg2 serta sampel diffusion couple paduan $\mathrm{U}-7 \mathrm{Mo} / \mathrm{Al}$ dengan pelat AIMg2 hasil pemanasan pada temperatur $550{ }^{\circ} \mathrm{C}$ selama 24 jam. Hasil analisis kekerasan mikro sampel sebelum dan setelah pemanasan menggunakan metode kekerasan mikro Vickers ditunjukkan pada Tabel 1. Besar kekerasan mikro sampel kelongsong AIMg2 dan paduan ingot $\mathrm{U}-7 \mathrm{Mo}$ tanpa pemanasan diperoleh masing-masing sebesar 64,62 dan 340,45 HV, sedangkan kekerasan mikro dari sampel kelongsong AIMg2 dan paduan ingot U-7Mo, serta sampel diffusion couple $\mathrm{U}-7 \mathrm{Mo} / \mathrm{Al}$ dengan pelat AIMg2 setelah pemanasan pada temperatur $550^{\circ} \mathrm{C}$ selama 24 jam menghasilkan senyawa $\mathrm{U}(\mathrm{Al}, \mathrm{Mo})_{\mathrm{x}}$ diperoleh berturut-turut adalah 52,34; 303,16 dan 497,34 HV[17,18]. Dari ketiga sampel uji diperoleh nilai kekerasan paling besar pada zona antarmuka atau senyawa $\mathrm{U}(\mathrm{Al}, \mathrm{Mo})_{\mathrm{x}}$ bila dibandingkan dengan kelongsong AlMg2 dan juga paduan U-7Mo. Perbedaan kekerasan ini menunjukkan bahwa pada pengujian interdifusi menggunakan metode diffusion couple menghasilkan senyawa baru (U,Mo)Alx pada zona antarmuka yang memiliki karakter berbeda termasuk sifat kekerasannya.

Tabel 1. Kekerasan diffusion couple U-7Mo dan AIMg setelah pemanasan $550^{\circ} \mathrm{C}$

\begin{tabular}{|c|c|c|}
\hline Sampel & $\begin{array}{c}\text { Kekerasan } \\
\text { mikro } \\
\text { tanpa } \\
\text { pemanasan } \\
\text { (HV) }\end{array}$ & $\begin{array}{c}\text { Kekerasan } \\
\text { mikro } \\
\text { dengan } \\
\text { pemanasan } \\
(\mathrm{HV})\end{array}$ \\
\hline $\begin{array}{c}\text { Kelongsong } \\
\text { AlMg2 }\end{array}$ & 64,62 & 52,34 \\
\hline Paduan U-7Mo & 340,45 & 303,16 \\
\hline $\begin{array}{c}\text { Senyawa } \\
(\text { U,Mo)Al }\end{array}$ & - & 497,34 \\
\hline $\begin{array}{c}\text { Senyawa } \\
(U, M o) A l_{3}\end{array}$ & - & $617[17,18]$ \\
\hline $\begin{array}{c}\text { Senyawa } \\
\text { U(Al,0,9Mo)Al } 4\end{array}$ & - & $653[17,18]$ \\
\hline
\end{tabular}

Tabel 1 menunjukkan bahwa kelongsong AIMg2 mempunyai kekerasan menurun setelah mengalami pemanasan dari 64,62 HV menjadi 52,34 HV, demikian halnya dengan paduan ingot U-7Mo kekerasannya menurun dari 340,45 HV menjadi 303,16 HV setelah mengalami pemanasan. Hal ini disebabkan oleh perubahan ukuran butir menjadi lebih halus (penghalusan butir), sedangkan kekerasan senyawa (U,Mo)Alx pada zona antarmuka diperoleh sebesar 497,34 HV. Kekerasan senyawa $(\mathrm{U}, \mathrm{Mo}) \mathrm{Al} \times \mathrm{d}$ diperoleh lebih besar bila dibandingkan dengan kekerasan kelongsong AlMg2 dan paduan U-7Mo. Pada temperatur pemanasan sebesar $550{ }^{\circ} \mathrm{C}$ terjadi reaksi interdifusi logam pemadu Mo dan matriks $\mathrm{Al}$ membentuk layer (U,Mo)A $\mathrm{I}_{\mathrm{x}}$ serta terjadi mekanisme larut padat (solid solution) antara uranium, Mo dan matriks A[16], dimana senyawa $U, M o) A l_{x}$ mempunyai kekerasan yang lebih besar dari paduan 
kelongsong AIMg2 dan paduan U-7Mo seperti yang dituangkan pada Tabel 1. Besar kekerasan layer (U,Mo)Alx yang diperoleh dibandingkan dengan hasil penelitian sebelumnya, dimana layer $(\mathrm{U}, \mathrm{Mo}) \mathrm{Al}_{3}$ mempunyai kekerasan mikro sebesar $617 \mathrm{HV}$ dan $\mathrm{U}(\mathrm{Al}, 0,9 \mathrm{Mo}) \mathrm{Al}_{4}$ sebesar $653 \mathrm{HV}^{[17,18]}$.

\section{SIMPULAN}

Analisis mikrostruktur yang didukung oleh analisis DTA diketahui bahwa paduan U-7Mo/Al mempunyai kompatibilitas panas yang baik hingga temperatur $500^{\circ} \mathrm{C}$. Proses pemanasan pada temperatur $580,16{ }^{\circ} \mathrm{C}$ telah terjadi interdifusi partikel $\mathrm{U}-7 \mathrm{Mo}$ dengan matriks Al menyebabkan terjadi perubahan fasa $\alpha+\delta$ menjadi $\alpha+\gamma$ yang disertai dengan pembentukan fasa metastabil $\mathrm{U}(\mathrm{Al}, \mathrm{Mo})_{x}$ pada temperatur $630,37{ }^{\circ} \mathrm{C}$ hingga $679,14{ }^{\circ} \mathrm{C}$. Peleburan uranium terjadi pada temperatur $1109,04^{\circ} \mathrm{C}$ yang diakhiri dengan reaksi dekomposisi $\mathrm{U}(\mathrm{Al}, \mathrm{Mo}) \mathrm{x}$ menjadi senyawa UAlx (UAI 4 , $\mathrm{UAl}_{3}$ dan $\mathrm{UAl}_{2}$ ) dan senyawa U-Mo pada temperatur $1328,34{ }^{\circ} \mathrm{C}$ hingga $1365,17{ }^{\circ} \mathrm{C}$. Hasil analisis mikrostruktur menggunakan SEM terjadi senyawa $\mathrm{UAl}_{\mathrm{x}}\left(\mathrm{UA} \mathrm{l}_{4}, \mathrm{UAl}_{3}\right.$ dan $\cup A l_{2}$ ) menunjukkan terbentuknya interaction layer. Hal ini sama dengan yang terjadi pada bahan bakar U-7Mo/Al yang diiradiasi dengan burn up $58 \%$, terjadi interdifusi antara paduan $\mathrm{U}-7 \mathrm{Mo}$ dengan matriks $\mathrm{Al}$ menghasilkan fasa metastabil $\mathrm{U}(\mathrm{Al}, \mathrm{Mo})_{x}$ yang berubah menjadi layer $(\mathrm{U}, \mathrm{Mo}) \mathrm{Al}_{7}$, presipitat $\mathrm{UMo}_{2} \mathrm{Al}_{20}, \quad(\mathrm{UMo}) \mathrm{Al}_{3}-\mathrm{Al}$ dan mem-bentuk boundary atau aglomerat senyawa $U A I_{x}\left(U A I_{4}, U A l_{3}\right.$ dan $\left.U A l_{2}\right)$. Proses interdifusi menyebabkan terbentuknya interaction layer dan fenomena ini tidak diharapkan dalam bahan bakar dispersi $\mathrm{U}-\mathrm{Mo} / \mathrm{Al}$ karena layer senyawa $(\mathrm{U}, \mathrm{Mo}) \mathrm{Al} \times$ memiliki kekerasan mikro lebih besar dan densitas lebih rendah dari pada densitas rata-rata U-7Mo/Al. Analisis kekerasan mikro menunjukkan bahwa senyawa $\mathrm{U}(\mathrm{Al}, \mathrm{Mo}) \times$ pada zona antarmuka mempunyai kekerasan mikro paling besar bila dibandingkan U-7Mo dan juga kelongsong AlMg2 yaitu masing-masing sebesar 497,34; 303,16 dan 52,34 HV.

\section{DAFTAR PUSTAKA}

[1] Suwardi, (2012), Performance Predic-tion Of High Density Nuclear fuel Plate Containing U-7\%Mo/Al. Jurnal IImiah Daur Bahan Bakar Nuklir "URANIA". Vo.18 No.3, Oktober 2012, hal 163-171. ISSN No. 0852-4777. Akreditasi No. 395/AU2/P2MI-LIPI/04/2012.

[2] Supardjo, Boybul, Agoeng Kadarjono, Aslina Br. Ginting, (2011), Pembuatan Pelat Elemen Bakar Mini UMo-AI Dengan Densitas Uranium 6 Dan $7 \mathrm{gU} / \mathrm{cm}^{3}$, Jurnal Teknologi Bahan Nuklir, Vol. 7 No. 2 , hal 107-122. ISSN No. 1907-2635. Akreditasi No. 261/AU1/P2MI-LIPI/05/2010.

[3] E. Perez, Y.H. Sohn, D.D.Keiser, (2009), U-Mo/Al Alloys Diffusion Couples Fuel/Cladding Intraction, International Meeting on Reduced Enrichment for Research and Test Reactor, RERTR 2009-31'st, Kempinski Hotel Beijing Lufthansa Center Beijing, China, November 1-5, 2009.

[4] Supardjo, Kadarjono Agoeng, Ariadi Wisnu, (2010), Analisis Struktur Dan Komposisi Fase Paduan $\mathrm{U}-7 \% \mathrm{Mo}-\mathrm{x} \% \mathrm{Zr} \quad(\mathrm{x}=1,2,3 \%$ berat $)$ Hasil Proses Peleburan, Jurnal Teknologi Bahan Nuklir, Vol.6 No. 2 , hal 71-134. . ISSN No. 1907-2635. Akreditasi

No. 261/AU1/P2MI-LIPI/05/2010.

[5] Aslina Br.Ginting, Maman Kartaman, Supardjo (2015), Interaksi Bahan Bakar $\mathrm{U}_{3} \mathrm{Si}_{2}-\mathrm{Al}$ Dengan Kelongsong AlMg2 Pada Elemen Bakar Silisida TMU 2,96 $\mathrm{gU} / \mathrm{cm}^{3}$, Jurnal Ilmiah Daur Bahan Bakar Nuklir "URANIA", Februari, Vol. 21 No.1, hal 9-18. ISSN No. 0852-4777. Akreditasi No. 595/AU3/P2MI-LIPI/03/2015. 
[6] Aslina Br.Ginting, Supardjo, Agoeng Kadarjono, Dian Anggraini (2011), Pengaruh Kandungan Molibdenum Terhadap Perubahan Fasa dan Kapasitas Panas Ingot Paduan U-Mo", Jurnal ilmiah Daur Bahan Bakar Nuklir "URANIA", Juni, Vol. 17 No.2, hal 76-86. ISSN No. 0852-4777. Akreditasi No. 395/AU2/P2MI-LIPI/04/2012.

[7] Aslina Br.Ginting, Supardjo, (2012), Komparasi Analisis Reaksi Termokimia Matrik Al Dengan Bahan Bakar $\mathrm{U}-\mathrm{Mo} / \mathrm{Al}$ Dan $\mathrm{U}_{3} \mathrm{Si}_{2} / \mathrm{Al}$ Menggunakan Differential Thermal Analysis, Jurnal IImiah Daur Bahan Bakar Nuklir "URANIA", Juni, Vol. 18 No.1, hal 12-20. ISSN No. 0852-4777. Akreditasi No 395/AU2/P2MI-LIPI/04/2012.

[8] Leenaers, A. et.al, (2004), Post-Irradiation Examination on Uranium-7wt\% Molybdenum Atomized Dispersion Fuel, Journal of Nuclear Materials 335, page 39-47.

[9] J. Allenou, O. Tougait, M. Pasturel, X. Iltis, F. Charollais, M.C. Anselmet, P.Lemoine, (2011), Interdiffusion Beha-viors in Doped Molybdenum Uranium and Aluminium or Aluminium Siliocon Dispersion Fuel: Effects of the Microstructure, Journal of Nuclear Materials.

[10] Mirandau.M, Arico.S, Rosenbusch.M, Ortiz. M, Balart.S and Gribaudo.L, (2009), Characterization of the Interaction Layer Grown by Inter-diffusion Between U-7Mo and Al A356 Alloy at 550 and $340^{\circ} \mathrm{C}$, Journal of Nuclear Materials 384, page 268-273.

[11] Chang-Kyu Kim et,al, (1999), An Investigation on $\mathrm{\gamma}-U$ Phase Stability and Thermal Compatibility of Dispersion Fuel Meats Prepared with Atomized U-16at.\%Mo, U-14at.\%Mo-2at.\%Ru and U-14at.\%Mo-2at\%Os, RERTR, AEKI Hungary, October 4.
[12] Ryu, Ho Jin. Park, Jae Soon. Park, Jong Man and Kim, Chang Kyu, (2011), The Effect of Si-Rich Layer Coating on U-Mo with Al Interdiffusion, Journal Nuclear Engineering and Technology, Vol.43 No.2, April 2011.

[13] P. Hastuti, T. M. Sembiring, Suparjo, Suwardi, (2010). LAK Insersi Elemen Bakar Uji Silisida 3 Pelat Tingkat Muat 4,8 dan 5,8 $\mathrm{gU} / \mathrm{cm}^{3}$ di Teras RSG-GAS, PRSG-BATAN.

[14] Park, Jong Man. et.al. (2007). Phase Stability of U-Mo-Ti Alloys and Interdiffusion Behaviors of U-Mo-Ti/Al-Si. International Meeting On Reduced Enrichment for Research and Test Reactors (RERTR). Prague, Czech Republic.

[15] J.Gun, D.D.Keiser, B.D.Miller,T.R.Allen, D.M.Wacs, (2008), Radiation Effect on Microstructural Stability of RERTR Fuel, $12^{\text {th }}$ Annual Topical Meeting on Research Reactor Fuel Management, Nuclear Fuels and Materials Division, Idaho National Laboratory, P.O.Box 1265, Idaho Falls 83403 USA, March, 2008.

[16] D.D.Keiser, A.B.Robinson, D.E.Janney, J.F.Jue, (2008), Results of Recent Microstructural Characterization of Irradiated U-Mo Dispersion Fuels with Al Alloy Materials That Contain Si,12 $2^{\text {th }}$ Annual Topical Meeting on Research Reactor Fuel Management, Nuclear Fuels and Materials Division, Idaho National Laboratory, P.O.Box 1265, Idaho Falls 83403 USA, March,2008

[17] D.E.Burkes, D.M.Wacs, D.D.Keiser, J.F.Jue.Gan, F.J.Rice, R.Prabhakaran, B.Miller, and M.Okuniewski, (2008), Fresh Fuel Characterization of U-Mo Alloys, RERTR 2008,30th, International Meeting on Reduced Enrichment for Research and Test Reactor, October 5-9, 2008, Hamilton Crowne Plaza Hotel, Washington, D.C, USA.

[18] D.D.Keiser, J.F.Jue and D.E.Burkes, (2007), Characterization and Testing of 
Monolithic RERTR Fuel Plates,

Transaction, 11 th International Topical Meeting, Center de Congres, Lyon, France,11-15 March 2007, Idaho National Laboratory, P.O.Box 1625,MS 6188, Idaho Falls, ID 83403-6188, USA. 